\title{
RESPONSE
}

\section{Imagining a World Beyond the Prison Pandemic Justin Piché}

$\mathrm{I}$

$t$ is 15 December 2021. I glance out my office window. Large flakes of

snow dot the sky and seem to hang in the air for what seems like forever. There is a stillness to it all. It is beautiful yet haunting at the same time because it is all too familiar.

I open my computer, click on my workflow folder and pull-up the todo-list. At the top of list is an instruction to "revise + submit op-ed". I give my tired head a shake and open the op-ed file. "Here we go again - time to get to work," I thought to myself as I went over the changes my colleagues made to the draft we threw together the day before in a panic because a COVID-19 outbreak had closed another provincial jail in Ontario. Imagine, an abolitionist in a panic over a jail closure. Normally a cause for celebration, at this stage in the pandemic, where the urgency to depopulate prisons has largely dissipated, a jail closure results in the emergency release of some, but the transfer of far more imprisoned people to already crowded sites of human caging in other communities - some near, others far away - where they will endure segregation-like conditions for a period of at least 14 days in the name of public health and community safety.

This op-ed, like the ones written before, followed a familiar pattern. Congregate settings are vectors of COVID-19 transmission. Check. Jails, prisons and penitentiaries are no exception. Check. Infections amongst prisoners and prison staff in Canada were limited during the first few months of the pandemic because of efforts to dramatically reduce the number of people locked-up. Check. Rates of police-reported victimization did not spike as a result even though governments failed to provide criminalized people with basic necessities like housing. Check. Yet depopulating these sites of confinement have been abandoned as COVID-19 infections linked to them and the use of segregation-like measures in the name of limiting transmission skyrocketed. Check. Predictably, the system is buckling. Check. This need not happen, but here we are again. Check. Go back to what worked during the first wave and build off those lessons. For public health, for community safety, Contain COVID-19, not people. Check. Rinse. Repeat.

How many times does this need to be written or said until sustained action is taken to enhance our collective health, well-being and safety? When will the (prison) pandemic end? Amidst the clouds and the storm of 
another COVID-19 winter it is hard to see beyond the horizon. It is hard to imagine a world beyond the prison, a world beyond the pandemic. Yet we must, through words, but also through collective struggle.

We must because as the contributors to this issue vividly highlight there is no justice to be found through human caging, in "Killing Time" (Steel Door Studios, 2020) and killing people - whether through bursts of state violence or neglect stretched over many years. Is it justice when one is subject to the slow violence of life imprisonment, the more 'humane' counterpart to capital punishment, described in painful detail by Yves Réal Côté and Alana Abramson (2022)? Is it justice when penal system actors are all too willing to cage people when they require compassion and care as shown by James Ruston (2022)? Is it justice when the violence of state actors behind bars is normalized to the point that imprisoned people do not even question its mundane exercise as explored by Mark Stobbe (2022)? Is it justice when solitary confinement is recognized as torture yet still effectively exists under new names as shown by Charles Diorio (2022)? Is it justice when people have done their time, yet continue to face barriers long after they have served their sentence, including in the academy of all places, as documented in pieces by Lukas Carey and colleagues (2022a, 2022b), including Adam Grant, Scott Tompkins, Andreas Aresti and Sacha Darke? Is it justice when we knowingly expose people to preventable diseases and the prospect of death as we have during the COVID-19 pandemic, including Dean Roberts (2022) and Matthew Feeney (2022), who chronicle devastating outbreaks they have survived and their on-going ramifications for incarcerated people from their respective prison cells still today?

No, this is not justice. This is violence and it must stop. Much of what will come after is unknown, it is "unfinished" as the late Thomas Mathiesen (2015) - a Norwegian scholar and prison abolitionist - would say. It is past time to embrace such uncertainties instead of the devastating certainties of human caging and imagine a world beyond the prison pandemic plaguing every nation.

\section{REFERENCES}

Carey, Lukas, Adam Grant and Scott Tompkins (2022) "Swinging Doors: An Autoethnographic Look at the Challenges Faced by Previously Incarcerated People in the USA and Australia", Journal of Prisoners on Prisons, 30(1): 38-63. 
Carey, Lukas, Andreas Aresti and Sacha Darke (2022) "What Are the Barriers to the Development of Convict Criminology in Australia?", Journal of Prisoners on Prisons, 30(1): 77-96.

Côté, Yves Réal and Alana Abramson (2022) "The Million Dollar Man: Reflections on Capital Punishment by a Canadian Lifer", Journal of Prisoners on Prisons, 30(1): 7-18.

Diorio, Charles (2022) "Solitary Confinement by Another Name Remains Solitary", Journal of Prisoners on Prisons, 30(1): 32-37.

Feeney, Matthew (2022) "MSOP's COVID-19 Response was a Disaster", Journal of Prisoners on Prisons, 30(1): 117-124.

Mathiesen, Thomas (2015[1974]) The Politics of Abolition Revisited, London: Routledge.

Roberts, Dean (2022) “CSC's COVID-19 Response: Inside Canada's First Federal Penitentiary Outbreak at Mission Medium", Journal of Prisoners on Prisons, 30(1): 100-116.

Steel Door Studios (2020) “Killing Time”. Retrieved from https://steeldoorstudios.com/ portfolio-1/

Stobbe, Mark (2022) "The Rarity of Prisoner Complaints Arising from GuardAdministered Violence: A Tentative Explanation”, Journal of Prisoners on Prisons, 30(1): 19-31.

\section{ABOUT THE AUTHOR}

Justin Piché, PhD is an Associate Professor in the Department of Criminology and Director of the Carceral Studies Research Collective at the University of Ottawa. He is also a member of the Criminalization and Punishment Education Project and Co-editor of the Journal of Prisoners on Prisons. During the COVID-19 pandemic, he has been tracking coronavirus infections and measures in Canadian jails, prisons, and penitentiaries as part of the Prison Pandemic Partnership. 